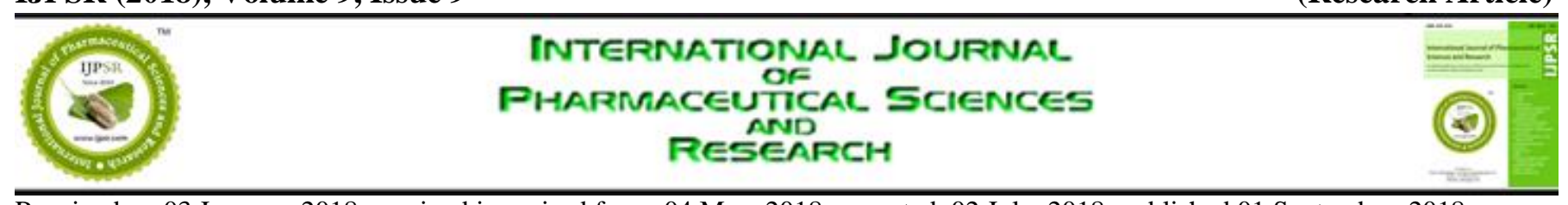

Received on 03 January, 2018; received in revised form, 04 May, 2018; accepted, 02 July, 2018; published 01 September, 2018

\title{
FORMULATION DEVELOPMENT AND EVALUATION OF CANDESARTAN BUCCAL TABLETS
}

Bookya Padmaja ${ }^{*}$, Shoba Rani Satla ${ }^{2}$ and Ramakrishna Raparla ${ }^{1}$

Department of Pharmaceutics 1, Vaageswari Institute of Pharmaceutical Sciences, Karimnagar - 505481, Telangana, India.

Department of Pharmaceutical Chemistry ${ }^{2}$, Center for Pharmaceutical Sciences, IST, JNTUH, Hyderabad - 500085, Telangana, India.

Keywords:

Candesartan,

Carbopol, Hydroxypropyl methylcellulose, Sodium alginate

\section{Correspondence to Author:}

Bookya Padmaja

Assistant Professor,

Department of Pharmaceutics,

Vaageswari Institute of Pharmaceutical

Sciences, Karimnagar - 505481,

Telangana, India.

E-mail: bookyapadmaja@gmail.com

\begin{abstract}
Buccal tablets are prepared by direct compression method using different polymers like carbopol, hydroxypropyl methylcellulose and sodium alginate. Nine formulations were prepared while (F1) to (F3) were prepared by taking individual concentrations whereas all the remaining formulations were prepared by taking combinations of polymers. Aim of study is to develop and optimize mucoadhesive buccal tablets of candesartan by direct compression method. All the batches were evaluated for thickness, weight variation, hardness and content uniformity. In-vitro release study is carried and release mechanisms were explored. Individual carbopol concentration (F1) has high swelling index with low water absorption ratio. Individual concentration of sodium alginate (F3) obtained high drug release, while low concentration of carbopol and high concentration of hydroxypropyl methylcellulose in combinations (F4) gave $86 \%$ drug release and with equal ratios of carbopol and hydroxypropyl methylcellulose (F7) gave $88 \%$ drug release. But low concentration of hydroxypropyl methylcellulose and high concentration of sodium alginate (F5) in combination form gave 95\% drug release. While equal ratios of both hydroxypropyl methylcellulose and sodium alginate in combination (F8) gave 98\% drug release. Among all formulations (F3) sodium alginate showed 93\% drug release, while (F7) with equal ratio of hydroxypropyl methylcellulose and sodium alginate showed $98 \%$ drug release within $8 \mathrm{~h}$. Compared to all polymers sodium alginate showed good drug release either in individual or combinations. All formulations followed zero order release kinetics.
\end{abstract}

INTRODUCTION: Historically oral route of drug administration has been the one used most for both conventional as well as novel drug delivery ${ }^{1}$.

\begin{tabular}{|c|c|}
\hline \multirow[t]{2}{*}{ QUICK RESPONSE CODE } & $\begin{array}{c}\text { DOI: } \\
\text { 10.13040/IJPSR.0975-8232.9(9).3827-32 }\end{array}$ \\
\hline & $\begin{array}{l}\text { Article can be accessed online on: } \\
\qquad w w w . i j p s r . c o m\end{array}$ \\
\hline ○i & 3040/IJPSR.0975-8232.9(9).3827-32 \\
\hline
\end{tabular}

The concept of muco adhesion was introduced into controlled drug delivery in 1980's which become a major part of novel drug delivery system in the recent era.

Some of the potential sites for attachment of any mucoadhesive system are included in buccal cavity, nasal cavity, eyes, vagina, rectal, sublingual route and gastrointestinal area ${ }^{2}$. Mucoadhesive polymers are able to interact with mucus which is secreted by the underlying tissue. 
The concept of mucoadhesive polymer has been accepted as a promising strategy to prolong the residence time and to improve localization of drug delivery systems on various membranes ${ }^{3}$. Buccal delivery of drugs is an alternative to oral route of drug administration this buccal route has numerous advantages like good accessibility, robustness of epithelium, facile removal of dosage form in case of need, relatively low enzymatic activity prevent drug degradation in gastro intestinal tract by avoiding hepatic first pass metabolism ${ }^{4}$. Candesartan belongs to class of angiotensin receptor antagonist which acts by binding selectively and non-competitively to angiotensin II receptor type 1 thus preventing actions of angiotensin II. Aim of the work is to develop buccal tablets for treatment of hypertension and congestive heart failure ${ }^{5}$.

\section{MATERIALS AND METHODS:}

Materials: Candesartan was a gift sample from Aurobindo Pharma Ltd., Hyderabad. Carbopol, hydroxy propyl methylcellulose and sodium alginate were received from Loba Chemicals, Mumbai. Sodium saccharine, talc, magnesium stearate and mannitol were procured from S.D. Fine Chemicals, Mumbai.

Preparation of Buccal Tablets: Candesartan mucoadhesive buccal tablets are prepared by direct compression method. All the ingredients were passed through a 60 mesh sieve. Required quantity of drug, polymers in individual, combinations are taken and mixed properly. Powder blend was lubricated with magnesium stearate for 3-5 min by adding talc as glidant. Finally the powder blend was evaluated for pre-compression studies and directly compressed using $10 \mathrm{~mm}$ punches on 12 station compression machine (Sai Pharmatech Ltd, India) with tablet weight of $100 \mathrm{mg}^{6}$. Composition of prepared formulations was shown in Table 1.

Precompression parameters: Powder blends were evaluated before compression to assess the flow properties $^{7,8.9}$.

\section{TABLE 1: FORMULA OF CANDESARTAN BUCCAL TABLETS}

\begin{tabular}{cccccccccc}
\hline Ingredients (mg) & CBF1 & CBF2 & CBF3 & CBF4 & CBF5 & CBF6 & CBF7 & CBF8 & CBF9 \\
\hline Candesartan & 30 & 30 & 30 & 30 & 30 & 30 & 30 & 30 & 30 \\
Carbopol & 30 & - & - & 10 & - & 10 & 15 & - \\
HPMC & - & 30 & - & 20 & 10 & - & 15 & 15 \\
Sodium alginate & - & - & 30 & - & 20 & 20 & - & 15 & 15 \\
Sodium saccharine & 5 & 5 & 5 & 5 & 5 & 5 & 5 & 5 & 5 \\
Magnesium stearate & 3 & 3 & 3 & 3 & 3 & 3 & 3 & 3 \\
Talc & 2 & 2 & 2 & 2 & 2 & 2 & 2 & 2 & 2 \\
Mannitol & 30 & 30 & 30 & 30 & 30 & 30 & 30 & 30 & 30 \\
Total weight(mg) & 100 & 100 & 100 & 100 & 100 & 100 & 100 & 100 & 100 \\
\hline
\end{tabular}

HPMC: Hydroxypropyl methyl cellulose

Angle of Repose: It is direct measure of flow property of powders. It is the maximum angle that can be obtained between free standing surface of a powder heap and the horizontal plane. It is calculated by the following formula.

$$
\text { Angle of repose }(\theta)=\tan ^{-1}(\mathrm{~h} / \mathrm{r})
$$

Where $h=$ height of pile, $r=$ radius of pile.

Bulk Density: 25gm of powder blend was weighed accurately which was previously passed through 30\# sieve and transferred in $100 \mathrm{ml}$ graduated cylinder. Carefully measure powder level without compacting and read the unsettled apparent volume (Vo). Calculate the apparent bulk density in $\mathrm{gm} / \mathrm{ml}$ by following formula.

Bulk density $=$ Weight of powder $/$ Bulk volume
Tapped density: $25 \mathrm{gm}$ of drug was weighed accurately, which was previously passed through $30 \#$ sieve and transferred in $100 \mathrm{ml}$ graduated cylinder. Then mechanically tap cylinder containing the sample by raising the cylinder and allowing it to drop under its own weight using mechanically tapped density apparatus (Electro Lab, India).

The cylinder was tapped for 500 times initially tapped volume $\left(\mathrm{V}_{1}\right)$ was measured to the nearest graduated units. Tappings were repeated on additional 100 times and the tapped volume $\left(\mathrm{V}_{2}\right)$ was measured. The tapped bulk density was measured in $\mathrm{gm} / \mathrm{ml}$ by the following formula.

$$
\text { Tapped density }=\frac{\text { Volume of powder }\left(\mathrm{V}_{1}\right)}{\text { Tapped volume }\left(\mathrm{V}_{2}\right)}
$$


Carr's Index: It is simplest way for measuring free flow property of powder. Compressibility is an indication of ease with which a material can be induced to flow is given by $\%$ compressibility that is calculated by the following formula.

$$
\text { Carr's index }=\frac{\text { Tapped density }- \text { Bulk density }}{\text { Tapped density }} \times 100
$$

Hausner's Ratio: It is an indirect index of ease of powder flow. It is calculated by the following formula. Lower value of hausner ratio $(<1.25)$ indicates better flow properties than higher ones (>1.25). The results are given in Table 2 .

$$
\text { Hausner's ratio }=\frac{\text { Tapped density }}{\text { Bulk density }}
$$

\section{Post Compression Parameters:}

Weight Variation: Twenty tablets are selected from each formulation and average weight was checked on digital balance (Shimadzu, Japan). The tablets are weighed individually and compared with average weight. U.S. Pharmacopoeia allows a little variation in weight of tablet ${ }^{10}$.

Thickness: Tablets are randomly selected and their thickness was measured by using Vernier callipers (Pharma Labs, Ahmedabad, India) reading was recorded in millimetres ${ }^{11}$.

Hardness: Hardness of tablet is directly proportional to friability loss and convenient in handling the tablets. Breaking under the condition of transportation and handling before the use depends on its hardness. Monsanto hardness tester (E 30, Dwaraka Mai, India) is used to measure hardness of tablets for every batch ${ }^{12}$.

Drug Content: Content uniformity of candesartan buccal tablet was determined; from each batch ten tablets were weighed and finely powdered. An amount of powder equivalent to $4 \mathrm{mg}$ was accurately weighed and dissolved in $\mathrm{pH} 6.8$ phosphate buffer. The resulting solution was suitably diluted with $\mathrm{pH} 6.8$ phosphate buffer, analysed by using UV Spectrophotometer (Shimadzu, India) at $233 \mathrm{~nm}$. The results are given in Table 3 and 4.

Friability: Ten tablets were weighed $\left(\mathrm{W}_{0}\right)$ and placed in Roche friabilator (Electro Lab, India) which are rotated at $25 \mathrm{rpm}$ for $4 \mathrm{~min}$. After revolutions, tablets were dedusted and weighed again $(\mathrm{W})$. The percentage friability was measured by the following formula ${ }^{13}$.

$$
\% \text { Friability }=\frac{\text { Initial weight }- \text { Final weight }}{\text { Initial weight }} \times 100
$$

Where, $\mathrm{W}_{0}=$ Initial weight of tablet, $\mathrm{W}=$ Weight of tablet after revolution.

Swelling Studies: Buccal tablets were weighed individually $\left(\mathrm{W}_{1}\right)$ and placed separately in petridish containing $15 \mathrm{ml}$ of $\mathrm{pH} 6.8$ phosphate buffer. At regular time intervals $(1,2,3,4,5,6,7,8 \mathrm{~h})$ the buccal tablets were removed from the petridish and excess surface water was removed carefully with the filter paper. The swollen tablets are then reweighed $\left(\mathrm{W}_{2}\right)$ and swelling index (water uptake) was calculated according to the following equation ${ }^{14}$.

$$
\text { Swelling index }=\left[\left(\mathrm{W}_{2}-\mathrm{W}_{1}\right) / \mathrm{W}_{1}\right] \times 100
$$

Where, $\mathrm{W}_{1}=$ Initial weight of tablet, $\mathrm{W}_{2}=$ Weight of tablet after swelling.

In-vitro Drug Release Study: The prepared tablets were supposed to release drug from one side only therefore an impermeable backing membrane was placed on other side of tablet. The tablet was further fixed to a $2 \times 2 \mathrm{~cm}$ glass slide with a solution of cyanoacrylate adhesive. In-vitro drug release studies was carried out in $900 \mathrm{ml}$ of $\mathrm{pH} 6.8$ phosphate buffer for $8 \mathrm{~h}$ using Paddle apparatus Type II (Electro Lab, Mumbai, India) for $50 \mathrm{rpm}$ at $37 \pm 0.5^{\circ} \mathrm{C}$. At predetermined time intervals $5 \mathrm{ml}$ samples were withdrawn and replaced with fresh medium. Samples are analysed by UV spectrophotometer (Shimadzu, India) at $233 \mathrm{~nm}$. Mechanism of drug release is determined by best fit of release data to Zero, First order, KorsmeyerPeppas plots ${ }^{15}$.

Water Absorption Ratio and Wetting Time: A piece of tissue paper folded twice was placed in a petridish containing $5 \mathrm{ml}$ of water. A pre weighed tablet $\left(\mathrm{W}_{\mathrm{B}}\right)$ was placed on paper and the time for complete wetting was measured. Wetted tablet are reweighed $\left(\mathrm{W}_{\mathrm{A}}\right)$ and water absorption ratio is determined by formula 16 .

$$
\text { Water absorption ratio }(\mathrm{R})=\left(\mathrm{W}_{\mathrm{A}}-\mathrm{W}_{\mathrm{B}} / \mathrm{W}_{\mathrm{B}}\right) \times 100
$$

Where, $\mathrm{W}_{\mathrm{A}}=$ weight of tablet after absorption of water, $\mathrm{W}_{\mathrm{B}}$ = weight of tablet before absorption of water. 
Determination of Surface pH: Surface $\mathrm{pH}$ of prepared candesartan buccal tablets was determined to evaluate the possible irritation effects on buccal mucosa. Buccal tablets were placed in glass tube and allowed to come in contact with distilled water (12 $\mathrm{ml})$ and $\mathrm{pH}$ was measured with $\mathrm{pH}$ paper allowing it to equilibrate for $1 \mathrm{~min}^{17}$.
RESULTS: In present work Candesartan buccal tablets are prepared by direct compression method as it is feasible and simple.

The best parameters obtained for Candesartan buccal tablets are evaluated based on drug release.

\section{TABLE 2: EVALUATION DATA OF POWDER BLEND OF CANDESARTAN BUCCAL FORMULATIONS}

\begin{tabular}{cccccc}
\hline $\begin{array}{c}\text { Powder } \\
\text { Blends }\end{array}$ & $\begin{array}{c}\text { Angle of repose* } \\
(\boldsymbol{\theta})\end{array}$ & $\begin{array}{c}\text { Bulk density* } \\
(\mathbf{g m} / \mathbf{m l})\end{array}$ & $\begin{array}{c}\text { Tapped density* } \\
(\mathbf{g m} / \mathbf{m l})\end{array}$ & $\begin{array}{c}\text { Carr's index* } \\
(\boldsymbol{\%})\end{array}$ & $\begin{array}{c}\text { Hausner's } \\
\text { ratio* }\end{array}$ \\
\hline CBF1 & $19.03 \pm 0.11$ & $0.562 \pm 0.02$ & $0.636 \pm 0.02$ & $11.62 \pm 0.02$ & $1.131 \pm 0.07$ \\
CBF2 & $19.03 \pm 0.11$ & $0.566 \pm 0.06$ & $0.647 \pm 0.03$ & $15.91 \pm 0.04$ & $1.189 \pm 0.03$ \\
CBF3 & $17.17 \pm 0.11$ & $0.540 \pm 0.06$ & $0.642 \pm 0.06$ & $15.85 \pm 0.02$ & $1.189 \pm 0.08$ \\
CBF4 & $20.55 \pm 0.51$ & $0.549 \pm 0.05$ & $0.623 \pm 0.05$ & $11.85 \pm 0.06$ & $1.134 \pm 0.05$ \\
CBF5 & $19.03 \pm 0.11$ & $0.500 \pm 0.06$ & $0.647 \pm 0.03$ & $15.91 \pm 0.01$ & $1.189 \pm 0.06$ \\
CBF6 & $17.17 \pm 0.11$ & $0.540 \pm 0.06$ & $0.642 \pm 0.06$ & $15.85 \pm 0.04$ & $1.189 \pm 0.04$ \\
CBF7 & $20.55 \pm 0.51$ & $0.549 \pm 0.05$ & $0.623 \pm 0.05$ & $11.85 \pm 0.06$ & $1.134 \pm 0.02$ \\
CBF8 & $19.01 \pm 0.11$ & $0.546 \pm 0.05$ & $0.640 \pm 0.03$ & $11.15 \pm 0.08$ & $1.189 \pm 0.03$ \\
CBF9 & $17.17 \pm 0.11$ & $0.640 \pm 0.06$ & $0.642 \pm 0.06$ & $15.85 \pm 0.01$ & $1.189 \pm 0.06$ \\
\hline
\end{tabular}

Each value is an average of three determinations *

TABLE 3: EVALUATION DATA OF CANDESARTAN BUCCAL FORMULATIONS (CBF1 - CBF4)

\begin{tabular}{ccccc}
\hline Evaluation parameters & CBF1 & CBF2 & CBF3 & CBF4 \\
\hline${\text { Weight variation }(\mathrm{mg})^{\mathrm{a}}}^{\text {Thickness }(\mathrm{mm})^{\mathrm{b}}}$ & $99 \pm 0.86$ & $97.1 \pm 1.16$ & $106 \pm 3.57$ & $102 \pm 0.88$ \\
${\text { Friability }(\%)^{\mathrm{b}}}^{\mathrm{b}}$ & $4.40 \pm 0.01$ & $4.59 \pm 0.05$ & $5.32 \pm 0.01$ & $4.38 \pm 0.07$ \\
Hardness $\left(\mathrm{Kg} / \mathrm{cm}^{2}\right)^{\mathrm{c}}$ & $0.192 \pm 0.57$ & $0.198 \pm 0.12$ & $0.218 \pm 0.17$ & $0.236 \pm 0.27$ \\
Content uniformity $(\%)^{\mathrm{c}}$ & $4.10 \pm 0.23$ & $4.85 \pm 0.25$ & $5.41 \pm 0.05$ & $4.22 \pm 0.15$ \\
${\text { Swelling index }(\%)^{\mathrm{c}}}^{\text {Surface } \mathrm{pH}^{\mathrm{c}}}$ & $98.4 \pm 0.73$ & $101 \pm 1.61$ & $99.2 \pm 0.12$ & $99.1 \pm 0.40$ \\
${\text { Water absorption ratio }(\%)^{\mathrm{c}}}^{\mathrm{c}}$ & $72.28 \pm 0.04$ & $63.58 \pm 0.69$ & $68.15 \pm 1.58$ & $69.03 \pm 0.91$ \\
& $6.6 \pm 0.34$ & $6.5 \pm 0.07$ & $6.7 \pm 0.07$ & $6.9 \pm 0.01$ \\
\hline
\end{tabular}

Each value is an average of twenty determinations ${ }^{\mathrm{a}}$, Each value is an average of ten determinations ${ }^{\mathrm{b}}$, Each value is an average of three determinations ${ }^{c}$

TABLE 4: EVALUATION DATA OF CANDESARTAN BUCCAL FORMULATIONS (CBF5 - CBF9)

\begin{tabular}{|c|c|c|c|c|c|}
\hline Evaluation Parameters & CBF5 & CBF6 & CBF7 & CBF8 & CBF9 \\
\hline Weight variation $(\mathrm{mg})^{\mathrm{a}}$ & $105 \pm 0.88$ & $106 \pm 3.57$ & $102 \pm 0.88$ & $97.1 \pm 1.16$ & $106 \pm 3.57$ \\
\hline Thickness $(\mathrm{mm})^{\mathrm{b}}$ & $4.18 \pm 0.07$ & $5.32 \pm 0.01$ & $4.38 \pm 0.07$ & $5.22 \pm 0.01$ & $4.18 \pm 0.07$ \\
\hline Friability $(\%)^{\mathrm{b}}$ & $0.216 \pm 0.07$ & $0.116 \pm 0.07$ & $0.198 \pm 0.12$ & $0.218 \pm 0.17$ & $0.216 \pm 0.07$ \\
\hline Hardness $\left(\mathrm{Kg} / \mathrm{cm}^{2}\right)^{\mathrm{c}}$ & $4.15 \pm 0.15$ & $4.15 \pm 0.15$ & $4.85 \pm 0.25$ & $4.41 \pm 0.05$ & $4.15 \pm 0.15$ \\
\hline Content uniformity $(\%)^{\mathrm{c}}$ & $99.02 \pm 0.12$ & $99.2 \pm 0.12$ & $99.1 \pm 0.40$ & $98.4 \pm 0.73$ & $98.4 \pm 0.73$ \\
\hline Swelling index $(\%)^{\mathrm{c}}$ & $67.90 \pm 0.48$ & $65.92 \pm 0.74$ & $53.14 \pm 1.99$ & $63.70 \pm 1.81$ & $66.04 \pm 0.12$ \\
\hline Surface $\mathrm{pH}^{\mathrm{c}}$ & $6.9 \pm 0.09$ & $6.8 \pm 0.10$ & $6.6 \pm 0.20$ & $6.7 \pm 0.46$ & $6.9 \pm 0.12$ \\
\hline Water absorption ratio $(\%)^{\mathrm{c}}$ & $15.41 \pm 0.44$ & $38.4 \pm 0.34$ & $36.2 \pm 0.34$ & $23.1 \pm 0.24$ & $35.46 \pm 0.14$ \\
\hline
\end{tabular}

Each value is an average of twenty determinations ${ }^{\mathrm{a}}$, Each value is an average of ten determinations ${ }^{\mathrm{b}}$, Each value is an average of three determinations ${ }^{c}$

TABLE 5: KINETICS DATA OF CANDESARTAN BUCCAL TABLET

\begin{tabular}{cccccc}
\hline Batch no. & Zero order $\left(\mathbf{R}^{2}\right)$ & First order $\left(\mathbf{R}^{2}\right)$ & Higuchi $\left(\mathbf{R}^{2}\right)$ & Korsmeyer-Peppas $\left(\mathbf{R}^{2}\right)$ & n \\
\hline CBF1 & $0.998 \pm 0.35$ & $0.945 \pm 0.25$ & $0.922 \pm 0.45$ & $0.999 \pm 0.43$ & $0.898 \pm 0.15$ \\
CBF2 & $0.997 \pm 0.78$ & $0.957 \pm 0.77$ & $0.886 \pm 0.29$ & $0.997 \pm 0.34$ & $0.958 \pm 0.16$ \\
CBF3 & $0.993 \pm 0.76$ & $0.970 \pm 0.65$ & $0.901 \pm 0.77$ & $0.977 \pm 0.57$ & $0.879 \pm 0.29$ \\
CBF4 & $0.982 \pm 0.67$ & $0.908 \pm 0.35$ & $0.865 \pm 0.66$ & $0.992 \pm 0.82$ & $0.939 \pm 0.94$ \\
CBF5 & $0.997 \pm 0.78$ & $0.933 \pm 0.25$ & $0.899 \pm 0.43$ & $0.993 \pm 0.25$ & $0.961 \pm 0.89$ \\
CBF6 & $0.996 \pm 0.25$ & $0.955 \pm 0.99$ & $0.930 \pm 0.14$ & $0.993 \pm 0.85$ & $0.841 \pm 0.15$ \\
CBF7 & $0.991 \pm 0.13$ & $0.975 \pm 0.65$ & $0.902 \pm 0.34$ & $0.997 \pm 0.87$ & $0.903 \pm 0.04$ \\
CBF8 & $0.992 \pm 0.98$ & $0.962 \pm 0.67$ & $0.885 \pm 0.78$ & $0.994 \pm 0.29$ & $0.935 \pm 0.12$ \\
CBF9 & $0.995 \pm 0.05$ & $0.975 \pm 0.05$ & $0.937 \pm 0.45$ & $0.995 \pm 0.34$ & $0.925 \pm 0.18$ \\
\hline
\end{tabular}

*Each value is an average of three determinations \pm S.D. SD: Standard deviation 


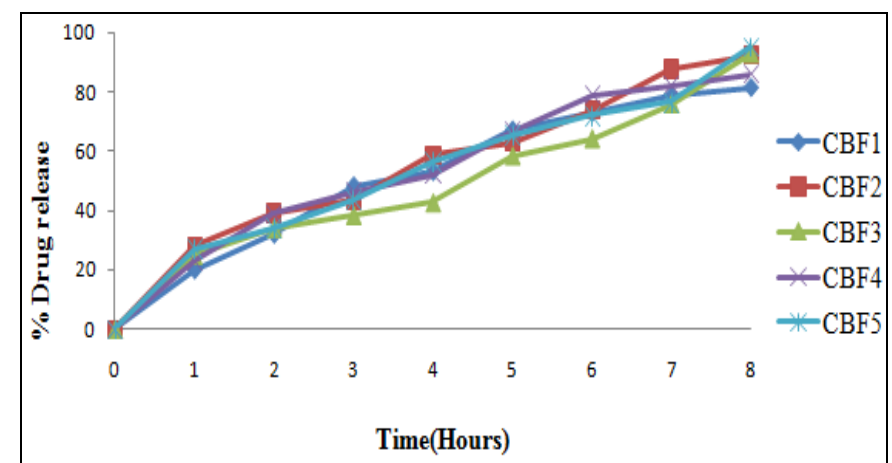

FIG. 1: CUMULATIVE \% DRUG RELEASE PLOT OF CANDESARTAN BUCCAL TABLETS (CBF1-CBF5)

DISCUSSION: In the present study direct compression method was employed for preparation of candesartan buccal tablets. Powder blends are found to have good flow properties within prescribed limits. Bulk density was found in the range of $0.500-0.640(\mathrm{gm} / \mathrm{ml})$ and tapped density between $0.623-0.647(\mathrm{gm} / \mathrm{ml})$ for all the formulations. Compressibility index values 11.15 $15.91 \%$ which were found to be good flow with Hausner's ratio values in the range of 1.131-1.189 for all powder blends. This was further supported by the angle of repose values between 17.17$20.55^{\circ}$. As it was below $30^{\circ}$ powder blend was found to have good flow properties.

All the tablets are having bevelled edged flat surface in round shape with white colour. Average weight of the tablets was in the range of 97-106 mg. Thickness of tablets was in the range of 4.18$5.32 \mathrm{~mm}$. Hardness of tablets is determined by Monsanto hardness tester and found in range of $4.10-5.41 \mathrm{~kg} / \mathrm{cm}^{2}$. As the aim of study is to release drug slowly hence hardness was kept in high range. Friability of all tablets is less than $1 \%$ with range of $0.116-0.236 \%$ by acceptable limits which indicate formulations have good mechanical strength.

All the prepared formulations are subjected for content uniformity with range of 98.4-101 \%. It was observed that all the formulations were as per I.P. specification limits (90.0 - 110.0\%). Combination of carbopol and hydroxypropyl methylcellulose polymer shows highest swelling index. Swelling index indicates the uptake of water into tablet matrix producing an increasing in weight. Surface $\mathrm{pH}$ was determined in order to investigate the possibility of any side effects in the oral cavity. Surface $\mathrm{pH}$ of the buccal tablets depends on the nature and composition of

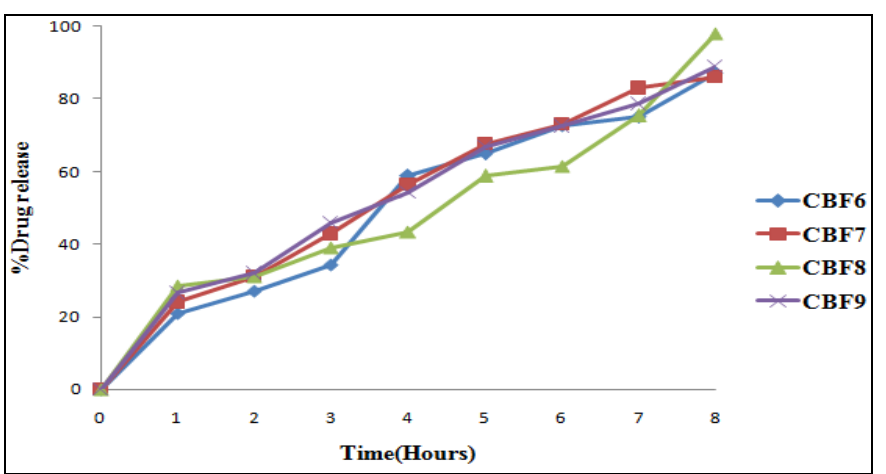

FIG. 2: CUMULATIVE \% DRUG RELEASE PLOT OF CANDESARTAN BUCCAL TABLETS (CBF6-CBF9)

mucoadhesive polymers. Surface $\mathrm{pH}$ of formulations is found in range of 6.5-7 hence, the prepared buccal tablet does not cause any irritation on mucosa. Swelling state of polymers in formulations was reported to be crucial for its boiadhesive behaviour, adhesion occurs shortly after swelling but the bond formed between the mucosal layer and polymer is not very strong.

Adhesion would increase with degree of hydration until point where over hydration leads to an abrupt drop in adhesive strength due to disentanglement at polymer/tissue interface. Individual carbopol concentration (F1) has high swelling index with low water absorption ratio. Combination of carbopol and hydroxypropyl methylcellulose (F4) obtained swelling index and water absorption ratio values at a higher extent. Individual concentration of sodium alginate (F3) obtained high drug release, but drug release of hydroxypropyl methylcellulose (F2) was nearer to sodium alginate in individual concentrations.

While low concentration of carbopol and high concentration of hydroxypropyl methylcellulose in combinations (F4) gave $86 \%$ drug release and with equal ratios of carbopol and hydroxypropyl methylcellulose (F7) gave $88 \%$ drug release. But low concentration of hydroxypropyl methyl cellulose and high concentration of sodium alginate (F5) in combination form gave $95 \%$ drug release. While equal ratios of both hydroxypropyl methyl cellulose and sodium alginate in combination (F8) gave $98 \%$ drug release.

CONCLUSION: In the present work an attempt was made to develop mucoadhesive buccal dosage form tablets of candesartan to improve better patient compliance. 
Buccal tablets of candesartan were prepared using different polymers such as hydroxypropyl methylcellulose, sodium alginate and carbopol by changing the polymer quantities in individual ratios and combinations to study effect of these polymers on the physico-chemical characters, swelling index, surface $\mathrm{pH}$, content uniformity, water absorption ratio and in-vitro drug release. Among all the nine formulations carbopol (F1) showed maximum swelling index value. Finally formulations (F8) with hydroxypropyl methylcellulose and sodium alginate in equal ratios gave $98 \%$ drug release which was most suitable for preparing buccal tablets. Compared to all polymers sodium alginate showed good drug release either in individual or combinations and all formulations were following zero order release kinetics.

ACKNOWLEDGEMENT: Authors express their sincere thanks to Dr. G. Srinivas Reddy, management for providing required facilities to carry out this research work.

CONFLICT OF INTEREST: All authors have none to declare.

\section{REFERENCES:}

1. Shalini $\mathrm{M}$ and Kothiyal P: Formulation and evaluation of buccal patches of Simvastatin by using different polymers. Pharma Inn 2012; 1(7): 87-92.

2. Raghavendra NG, Sunil F and Keyur P: Formulation and invitro evaluation of mucoadhesive buccal patches containing Zolmitriptan using gel forming polymers. Pelagia Res. Lib 2012; 3(1): 47-57.

3. Meghana $\mathrm{C}$ and Chandrashekar: Formulation and evaluation of mucoadhesive buccal tablets of Repaglinide. RGHUS J Pharm Sci 2014; 4(4): 156-165.

4. Shailendra S, Gunjan S and Pankaj S: Formulation and evaluation of mucoadhesive buccal tablets of Zolmitriptan. W J Pharm Pharm Sci 2016; 5(7): 1402-1419.
5. Vinay C and Mohammed G: Formulation and evaluation of mucoadhesive buccal tablets of candesartan. J Drug Deli Thera 2015; 5(5): 56-63.

6. Sellappan V and Srinivas P: Formulation and in-vitro evaluation of Losartan potassium mucoadhesive buccal tablets. Asian J Pharm Clin Res. 2013; 6(3): 125-130.

7. Shingala K, Singh C, Deepak D and Bhavin P: Formulation and evaluation of immediate release tablet of poorly soluble candesartan cilexetil. J Pharm Sci. Biosci Res 2013; 3(2): 77-90.

8. Vivekanand K, Abhishek R, Prashant K and Deshmukh: Formulation and evaluation of nisoldipine sublingual tablets using pullulan and chitosan for rapid oromucosal absorption. Adv in Pharmacol Pharm 2013; 1(1): 18-25.

9. Devendra R, Narhar HG, Vasant VP, Vinod M and Vijay P: Formulation and evaluation of fast dissolving tablet of albendazole. Int Curr Pharm J. 2012; 1(10): 311-316.

10. Ankit P, Mithum B, Girijesh P, Amit Joshi and Balkrishna D: Formulation and evaluation of bilayer tablet of candesartan and hydrochlorothiazide for treatment of hypertension. J Drug Del Thera 2013; 3(6): 21-35.

11. Sandhya P, Vijaya $P$ and Susmitha A: Formulation and evaluation of mucoadhesive buccal tablets of losartan by using natural polymers. Int J Pharm Anal Res. 2016; 5(2): 239-244.

12. Gururaj S, Raghavendra Rao NG and Narasimhareddy D: Formulation development and evaluation of terbutaline sulphate mucoadhesive buccal tablets. Int Res. J Pharm 2013; 4(3): 189-192.

13. Sanjit KR, Sweet N, Subhasis K and Ketousetuo K: Formulation and evaluation of sustained release bilayer tablets of Propranolol hydrochloride. Int J Pharm Pharma Sci 2015; 7(4): 264-269.

14. Venkateswara B and Ramanareddy KV: Formulation and evaluation of buccal mucoadhesive tablets of glipizide. W J Pharma Pharm Sci. 2015; 4(7):1804-1821.

15. Ahmed A, Laith Samein, Mowafaq $M$ and Ghareeb: Effects of mucoadhesive polymers combination on the properties of Lisinopril buccal tablets prepared by wet granulation method. Int J Pharm Pharma Sci 2013; 5(4): 340-343.

16. Biswajit B, Nabin $\mathrm{K}$ and Bhavesh B: Formulation and evaluation of repaglinide buccal tablet: ex-vivo bioadhesion study and ex-vivo permeability study. J Appl Pharma Sci 2014; 4(5): 96-103.

17. Balaji A and Vaddepalli R, Goud V: Formulation and evaluation of mucoadhesive buccal tablets by using natural polymer. Int.J.Pharm Sci. Res 2014; 5(11): 4699-4708.

How to cite this article:

Padmaja B, Satla SR and Raparla R: Formulation development and evaluation of Candesartan buccal tablets. Int J Pharm Sci \& Res 2018; 9(9): 3827-32. doi: 10.13040/IJPSR.0975-8232.9(9).3827-32.

All @ 2013 are reserved by International Journal of Pharmaceutical Sciences and Research. This Journal licensed under a Creative Commons Attribution-NonCommercial-ShareAlike 3.0 Unported License.

This article can be downloaded to ANDROID OS based mobile. Scan QR Code using Code/Bar Scanner from your mobile. (Scanners are available on Google Playstore) 